Tersedia online di: http://ejournal-balitbang.kkp.go.id/index.php/jra

\title{
PENAMBAHAN VITAMIN E DALAM PAKAN TERHADAP KUALITAS REPRODUKSI INDUK IKAN NILA (Oreochromis niloticus)
}

\author{
Evi Tahapari”, Jadmiko Darmawan, Adam Robisalmi, dan Priadi Setiyawan
}

\author{
Balai Riset Pemuliaan Ikan \\ Jl. Raya 2 Sukamandi, Subang, Jawa Barat 41256
}

(Naskah diterima: 20 Mei 2019; Revisi final: 16 Oktober 2019; Disetujui publikasi: 16 Oktober 2019)

\begin{abstract}
ABSTRAK
Penambahan vitamin E sintetis pada pakan induk sangat penting, karena vitamin E tidak dapat disintesis oleh ikan. Tujuan penelitian ini adalah untuk mengetahui penambahan vitamin E dalam pakan terhadap kualitas reproduksi induk ikan nila. Penelitian dilakukan di Balai Riset Pemuliaan Ikan (BRPI) Sukamandi selama tiga bulan. Pakan uji adalah pakan formulasi berkadar protein kasar 35,83\%36,13\% lemak kasar 8,17\%9,79\% BETN 43,10\%45,72\% dan serat kasar 1,98\%2,58\% dengan penambahan vitamin $\mathrm{E}$ berbeda, yaitu: A) 0 (kontrol), B) 150, C) 225, dan D) 300 mg/kg pakan. Ikan uji berumur 6,5 bulan sebanyak 80 ekor betina dan 40 ekor jantan, dan setiap induk ikan betina diberi tanda (tagging). Wadah ikan uji adalah jaring hapa berukuran $3 \mathrm{~m} \times 2 \mathrm{~m} \times 1,25 \mathrm{~m}$ sebanyak empat buah yang ditempatkan di kolam tanah seluas 6.000 $\mathrm{m}^{2}$ dengan ketinggian air $\pm 1 \mathrm{~m}$. Setiap jaring diisi 20 ekor induk betina dan 10 ekor induk jantan. Parameter yang diamati adalah: gonad somatik indeks, frekuensi pemijahan, fekunditas, diameter telur, derajat tetas telur, produksi larva, abnormalitas Iarva, dan gonad pada akhir percobaan. Sampling dilakukan setiap satu minggu sekali selama tiga bulan pemeliharaan. Hasil penelitian menunjukkan bahwa penambahan vitamin E $225 \mathrm{mg} / \mathrm{kg}$ pakan memberikan hasil terbaik, dapat meningkatkan produksi larva sebesar 78,55\% dibanding dengan tanpa penambahan vitamin E (kontrol). Jumlah induk memijah sebesar 85\% dengan jumlah frekuensi pemijahan terbanyak yaitu 28 kali dan total produksi larva tertinggi yaitu 37.927 ekor (produktivitas induk 2.231 larva/ekor) dan rataan fekunditas individu sebesar $1.886 \pm 513$ butir.
\end{abstract}

\section{KATA KUNCl: vitamin E; produktivitas; pakan induk; ikan nila}

ABSTRACT: Improving the reproductive quality of tilapia (Oreochromis niloticus) broodstock through vitamin E addition in feed. By: Evi Tahapari, Jadmiko Darmawan, Adam Robisalmi, and Priadi Setiawan

\begin{abstract}
The addition of synthetic vitamin $E$ in broodstock feed is a necessity due to fish inability to synthesized vitamin $E$. Currently, there is limited information on vitamin E requirement to boost the reproductive performance of tilapia. The purpose of this study was to determine the effects of vitamin $E$ in feed on the reproductive performance of tilapia broodstock. The study was conducted for three months at theSukamandi Fish Breeding Research Center. Thetest feeds were formulated feeds with crude protein content of $35.83 \% 36.13 \%$ crude fat $8.17 \% 9.79 \%$ NFE $43.10 \% 45.72 \%$ and crude fiber of $1.98 \% 2.58 \%$ with the addition of different vitamin E, namely: A) 0 (control), B) 150, C) 225, and D) $300 \mathrm{mg} / \mathrm{kg}$ of feed. The test fish were aged 6.5 months consisted of 80 females and 40 males, where each female was given a unique tagging code. The fish were reared in four hapa nets sized $3 \mathrm{~m} \times 2 \mathrm{~m} \times 1.25 \mathrm{~m}$ which were constructed in a pond of $6,000 \mathrm{~m} 2$ with a water level of $\pm 1 \mathrm{~m}$. Each hapa net contained 20 female and ten male broodstocks. The parameters observed were: gonadal somatic index, spawning frequency, fecundity, egg diameter, hatching rate, larval production, larval abnormalities, and gonadal development at the end of the experiment. Sampling was done once a week during the three months of the experiment. The results showed that the addition of vitamin $E$ $225 \mathrm{mg} / \mathrm{kg}$ of feed gave the best results. Larval production increased by $78.55 \%$ compared to without the addition of vitamin $\mathrm{E}$ (control). The percentage of spawning broodstock was $85 \%$ with the highest number of spawning frequencies of 28 times, the highest total larvae production of 37,927 larvae (broodstock productivity 2,231 larvae/fish), and the average individual fecundity of $1,886 \pm 513$ eggs.
\end{abstract}

KEYWORDS: vitamin E; productivity; broodstock feed; tilapia

\footnotetext{
\# Korespondensi: Balai Riset Pemuliaan Ikan.

Jl. Raya 2 Sukamandi, Subang, Jawa Barat 41256, Indonesia.

Tel. +62260520500

E-mail: evitahapari@yahoo.co.id
} 


\section{PENDAHULUAN}

Permintaan konsumsi ikan nila dari tahun ke tahun mengalami peningkatan yang signifikan. Kondisi ini tentunya harus diimbangi dengan peningkatan produksi sebagai upaya antisipatif dalam memenuhi kebutuhan.

Produksi ikan nila nasional menduduki peringkat pertama untuk jenis ikan budidaya yaitu sebesar 1,28 juta ton pada tahun 2017 dengan nilai produksi sebesar 27,9 triliun rupiah. Produksi ikan nila nasional tersebut didominasi oleh hasil kegiatan budidaya air tawar yang tersebar di berbagai daerah. Provinsi Jawa Barat merupakan produsen ikan nila terbesar dengan volume 343.361 ton, diikuti Sumatera Selatan, Jawa Tengah, Sumatera Barat, dan Sulawesi Utara (Pusat Data Statistik dan Informasi KKP, 2018). Tingginya produksi ikan nila nasional membawa Indonesia pada urutan kedua produsen ikan nila terbesar dunia. Produksi ikan nila global mencapai 5,7 juta ton dengan produsen terbesar adalah Cina, diikuti Indonesia, Mesir, Bangladesh, dan Vietnam (Miao, 2018). Untuk terus meningkatkan produksi ikan nila nasional tentunya harus didukung dengan ketersediaan benih yang mencukupi (kualitas, kuantitas, dan kontinuitas) sehingga permintaan pasar dapat terpenuhi. Ketersediaan benih merupakan faktor pembatas utama dalam pengembangan budidaya ikan.

Salah satu fase penting dalam siklus reproduksi ikan adalah proses pematangan gonad. Pematangan gonad dapat ditingkatkan melalui pemberian pakan induk yang mengandung nutrien penting (protein, lemak, vitamin) yang optimal. Nutrisi pada pakan induk dapat berpengaruh pada perkembangan gonad, fekunditas, dan perkembangan embrio (Roy \& Mollah, 2009; Utomo, 2009). Perbaikan pakan induk tidak hanya berpengaruh pada kualitas telur dan sperma, tetapi juga terhadap mutu dan jumlah benih yang dihasilkan (Izquierdo et al., 2001). Kurangnya nutrisi yang dibutuhkan dalam pakan dapat menjadi faktor utama penyebab gagalnya ikan matang gonad (Sukendi, 2005) terutama karena defisiensi vitamin (Waagbø, 2010).

Selain energi, ikan memerlukan materi lain berupa vitamin yang merupakan nutrien esensial dalam pakan ikan, karena ikan tidak dapat mensintesis sendiri di dalam tubuhnya. Kebutuhan vitamin oleh ikan bervariasi menurut spesies, ukuran, dan umur ikan (Izquierdo et al., 2001). Kadar vitamin E optimal dalam pakan sangat dibutuhkan untuk meningkatkan performa reproduksi selama proses pematangan gonad (Nascimento et al., 2014). Fungsi yang paling penting vitamin $\mathrm{E}$ adalah sebagai antioksidan, terutama untuk melindungi asam lemak tidak jenuh pada fosfolipid dalam membran sel, serta dapat mempercepat sekresi hormon reproduksi (Hamre, 2011; Napitu et al., 2013). Penambahan vitamin E dalam pakan juga dapat menurunkan tingkat stres pada induk ikan beluga (Huso huso) yang akan memijah karena perubahan lingkungan (Jalali et al., 2008). Vitamin E juga berfungsi sebagai pelindung dinding sel dari bahan beracun seperti timah, merkuri, benzen, dan radikal bebas yang dapat mengganggu kerja kelenjar endokrin dan berakibat pada keseimbangan produksi hormon. Vitamin E diangkut dari jaringan periferal ke gonad melalui hati bersama lipoprotein plasma (Lie et al., 1994 dalam Mokoginta et al., 2000). Vitamin E yang diberikan pada induk ikan akan dicerna pada usus halus dan disimpan pada beberapa jaringan tubuh seperti jaringan adiposa, hati, dan jaringan tubuh lainnya (Pour et al., 2011). Vitamin E juga berfungsi dalam mendukung peran enzim sitokrom P450 menyintesis kolesterol untuk pembentukan hormon reproduksi, dalam hal ini 17á-estradiol. Hormon 17áestradiol menstimulasi sintesis vitelogenin di hati. Vitamin E diangkut ke hati dalam bentuk kilomikron, yang selanjutnya dari hati dan seterusnya distribusinya mengikuti trigliserida dan lipid lainnya melalui lipoprotein ke jaringan lemak dan membran intra sel maupun ekstra sel (Takeuchi et al., 1988). Hal ini menunjukkan adanya peran nyata vitamin E pada proses reproduksi.

Hasil yang diperoleh pada penelitian sebelumnya bahwa penambahan vitamin E pada pakan ikan mampu meningkatkan performa reproduksi, antara lain: pada ikan patin Siam (Yulfiperius et al., 2003); ikan zebra, Danio rerio (Utomo et al., 2005; M ehrad et al., 2011); ikan nila, Oreochromis niloticus (Celik \& Altun, 2009; Ispir et al., 2011; Nascimento et al., 2014); ikan trout, Salmo labrax (Serezli et al., 2010); ikan komet, Carassius auratus (Arfah et al., 2013); ikan nilem, Ostheochilus hasselti, CV (Tarigan et al., 2017); ikan betutu, Oxyeleotris marmorata Bleeker 1852 (Wahyudi et al., 2016). Informasi kebutuhan nutrisi induk untuk kepentingan produksi benih yang baik masih sedikit dan umumnya standar nutrisi pakan yang digunakan masih mengandalkan kriteria umum untuk kegiatan pembesaran, padahal kebutuhan nutrien induk sangat spesifik. Jika dicermati, hasil penelitian sebelumnya terkait penambahan vitamin E menunjukkan bahwa pakan induk yang digunakan berkadar protein bervariasi $30 \% 40 \%$ Protein merupakan salah satu nutrien penting yang harus tercukupi dalam pakan induk guna memelihara gonad dan penampilan reproduksi. Protein hadir dalam telur ikan sebagai lipoprotein, hormon, dan enzim yang menentukan 
kualitas telur dan produksi larva (Coldebella et al., 2011). Pada penelitian ini pakan induk yang digunakan berkadar protein $35 \%$ sesuai yang direkomendasikan pada pakan induk ikan nila.

Hasil penelitian ini diharapkan akan melengkapi hasil penelitian sebelumnya yang dilaporkan oleh Pamungkas et al. (2014) bahwa pemberian vitamin E dengan dosis $225 \mathrm{mg} / \mathrm{kg}$ pakan memberikan keragaan terbaik terhadap dua parameter reproduksi ikan nila (perkembangan gonad dan frekuensi pemijahan). Penelitian ini bertujuan untuk mengetahui pengaruh penambahan vitamin E sintetis dalam pakan terhadap kinerja reproduksi ikan nila.

\section{METODE PENELITIAN}

\section{Desain Riset dan Lokasi Penelitian}

Desain riset menggunakan metode eksperimental dengan empat perlakuan; dengan dosis vitamin $\mathrm{E}$ berbeda. Ikan uji adalah 80 ekor induk ikan nila betina yang diberi tanda (tagging) dan 40 ekor induk jantan. Penelitian dilakukan di kolam dan hatchery Balai Riset Pemuliaan Ikan (BRPI) Sukamandi, Subang, Jawa Barat.

\section{Bahan dan Alat}

Pakan uji yang digunakan adalah pakan formulasi dengan kadar protein kasar 35,83\%36,13\%dan lemak kasar 8,17\%9,79\% Vitamin E yang digunakan dalam bentuk á-tokoferol dengan tingkat kemurnian 50\% (Ensafal Jufela Food 500). Wadah pemeliharaan ikan uji menggunakan empat buah jaring hapa berukuran $3 \mathrm{~m}$ $\times 2 \mathrm{~m} \times 1,25 \mathrm{~m}$ per wadah yang ditempatkan di kolam tanah berukuran $6.000 \mathrm{~m}^{2}$.

\section{Ikan Uji}

Ikan uji adalah induk ikan nila varietas Selfam hasil budidaya di Balai Riset Pemuliaan Ikan, Sukamandi. Jumlah induk ikan uji sebanyak 80 ekor betina dan 40 ekor jantan yang ditempatkan pada masing-masing wadah pemeliharaan (jaring) sebanyak empat buah. Umur induk ikan uji berkisar 6,5 bulan dengan bobot rata-rata 561,76 $\pm 104,28 \mathrm{~g}$. Untuk menyeragamkan tingkat kematangan gonad (TKG) ikan uji, sebelumnya dilakukan pemeliharaan induk jantan dan betina secara terpisah, kemudian dilakukan pemijahan secara massal, selanjutnya dipilih induk-induk yang mengerami telur sebanyak jumlah ikan uji yang dibutuhkan. Semua induk betina ikan uji dilakukan penandaan (tagging). Hal ini dimaksudkan untuk memudahkan dalam pengamatan perkembangan gonad pada setiap induk ikan. Sebelum dilakukan plotting terlebih dahulu ikan uji diadaptasikan terhadap pakan dan wadah pemeliharaan selama satu minggu.

\section{Pakan Uji}

Pakan uji yang digunakan adalah pakan formulasi (Tabel 1). Hasil analisis proksimat pakan dan analisis vitamin E pakan disajikan pada Tabel 2. Pakan uji diberikan sebanyak $3 \%$ dari biomassa ikan per hari dengan frekuensi pemberian dua kali pada pagi dan sore hari.

\section{Pengamatan dan Sampling}

Pengamatan perkembangan gonad, frekuensi pemijahan, fekunditas, diameter telur, derajat tetas telur, produksi larva, abnormalitas larva dilakukan setiap satu minggu sekali. Hal ini dimaksudkan untuk menjaga agar setiap ikan yg memijah dapat terpantau/ terdata. Karena jika ada ikan yg memijah tidak pada saat pengamatan, maka telur/larva dipastikan masih dalam pengeraman di dalam mulut induk ikan uji. Namun jika pengamatan dilakukan lebih dari satu minggu dikhawatirkan ada ikan yang memijah tidak terpantau/terdata karena dikhawatirkan larva sudah tidak dalam proses pengeraman dalam mulut induk ikan uji. Telur hasil pemijahan yang dierami oleh induk ikan tersebut kemudian dipindahkan ke dalam corong penetasan untuk diinkubasi sampai telur menetas. Sehingga dari hasil penetasan tersebut dapat dilihat derajat penetasan telur dan abnormalitas larva.

\section{Inkubasi Telur}

Proses penetasan telur dilakukan secara indoor dengan menggunakan wadah berbentuk corong. Telur hasil pemijahan alami (telur yang dierami) oleh setiap induk dikumpulkan dan dihitung menggunakan hand counter kemudian dipindahkan ke corong penetasan untuk diinkubasi sampai menetas.

\section{Parameter Uji}

Parameter yang diamati meliputi: gonad somatik indeks (GSI), frekuensi pemijahan, fekunditas, diameter telur, derajat tetas telur, abnormalitas larva, dan analisis gonad akhir perco baan. Pengamatan terhadap parameter GSI dimulai setelah satu minggu pemberian pakan percobaan melalui pembedahan ikan uji sebanyak satu ekor pada masing-masing perlakuan. Pengamatan GSI dilakukan setiap satu minggu sekali selama lima kali pengamatan. Abnormalitas (cacat) larva ikan diamati dari bentuk kepala, tubuh, dan atau ekor bengkok, tubuh menyusut atau lebih pendek dari ukuran normal maupun pembesaran kelopak mata. Pengamatan larva dilakukan selama lima hari setelah telur menetas. Sebagai parameter penunjang adalah kualitas sifat fisika-kimia air kolam pemeliharaan. 
Tabel 1. Komposisi pakan percobaan untuk induk ikan nila

Table 1. The composition of the experimental feed for tilapia broodstock

\begin{tabular}{lcccc}
\hline \multicolumn{1}{c}{$\begin{array}{c}\text { Bahan baku } \\
\text { Ingredients }\end{array}$} & \multicolumn{4}{c}{ Kom posisi dalam formulasi pakan } \\
Ingredients composition in feed formulations (\%)
\end{tabular}

Keterangan (Note):

1) Vitamin mix: vit. A $5.000 \mathrm{UI} / \mathrm{g}$; vit. D3 $1.200 \mathrm{UI} / \mathrm{g}$; vit. E $75 \mathrm{UI} / \mathrm{g}$; vit. K3 23,5 mg/g; vit. B1 $15 \mathrm{mg} / \mathrm{g}$; riboflavin $20 \mathrm{mg} / \mathrm{g}$; vit. B6 $20 \mathrm{mg} / \mathrm{g}$; vit. B12 0,01 mg/g; pantothenic acid 45,1 mg/g; niacin $100 \mathrm{mg} / \mathrm{g}$; folic acid $7 \mathrm{mg} /$ $\mathrm{g}$; biotin $0,2 \mathrm{mg} / \mathrm{g}$

2) Mineral mix (mg/g): CuSO4.5H2O 20; FeSO4.H2O 50; ZnO 200; Ca(IO3)2 7,5; MnO2 50; CoCO3.H2O 0,05; $\mathrm{Na} 2 \mathrm{SeO} 30,8$.

Tabel 2. Komposisi proksimat pakan, energi pakan, dan kandungan vitamin E pakan berdasarkan bobot kering

Table 2. Proximate composition of feed, feed energy, and vitamin E content of the experimental feed

\begin{tabular}{lcccc}
\hline \multicolumn{1}{c}{$\begin{array}{c}\text { Parameter } \\
\text { Parameters }\end{array}$} & \multicolumn{4}{c}{$\begin{array}{c}\text { Kom posisi nutrien pakan } \\
\text { Nutrient composition of feed (\%) }\end{array}$} \\
\hline Vitamin E (mg/kg pakan) & $\mathbf{A}$ & $\mathbf{B}$ & $\mathbf{C}$ & $\mathbf{D}$ \\
\cline { 2 - 6 } Vitamin E (mg/kg feed) & $\mathbf{0}$ & $\mathbf{1 5 0}$ & $\mathbf{2 2 5}$ & $\mathbf{3 0 0}$ \\
\hline Protein kasar (Crude protein) & 36.13 & 35.83 & 36.09 & 35.95 \\
Lemak kasar (Crude fat) & 9.47 & 8.67 & 9.79 & 8.17 \\
Serat kasar (Crude fibre) & 2.57 & 1.98 & 2.58 & 2.34 \\
BETN (NFE ) & 43.78 & 44.5 & 43.1 & 45.72 \\
DE (kkal/kg pakan/feed ) & $3,126.10$ & $3,068.82$ & $3,133.64$ & $3,063.02$ \\
C/P (kkal/g protein) & 8.65 & 8.56 & 8.68 & 8.52 \\
Vitamin E pakan/Nitamin E in feed $(\mu \mathrm{g} / \mathrm{g})$ & 14.92 & 384.38 & 419.97 & 483.08 \\
\hline
\end{tabular}

Keterangan (Note):

*) Analisis proksimat pakan dilakukan di Laboratorium Kimia PAU IPB, Bogor (Feed proximate analysis was done at PAU Chemical Laboratory IPB, Bogor)

*) Analisis kandungan vitamin E dilakukan di Laboratorium Pengujian Balai Besar Penelitian dan Pengembangan Pasca Panen Pertanian, Bogor (Vitamin E analysis was performed at the Laboratory of Central Research and Development of Post Harvest Agriculture, Bogor)

1) BETN (NFE): bahan ekstrak tanpa nitrogen (nitrogen free extract)

2) DE: digestible energy yang diperhitungkan dari $1 \mathrm{~g}$ protein $(3,5 \mathrm{kkal}) ; 1 \mathrm{~g}$ lemak $(8,1 \mathrm{kkal}) ; 1 \mathrm{~g}$ karbohidrat (2,5 kkal) (NRC, 1983) 


\section{Analisis Data}

Data keseluruhan yang diperoleh ditampilkan secara deskriptif komparatif dengan melihat pola kecenderungannya. Informasi yang didapat digunakan untuk menjelaskan fenomena yang terjadi.

\section{HASIL DAN BAHASAN}

Hasil analisis secara deskriptif menunjukkan bahwa penambahan dosis vitamin $\mathrm{E}$ berbeda dalam pakan memberikan pengaruh terhadap nilai gonad somatik indeks (GSI) (Gambar 1), fekunditas individu, frekuensi pemijahan, jumlah induk memijah, dan total produksi larva (Gambar 2). Namun relatif tidak berpengaruh terhadap diameter telur, derajat tetas telur, dan abnormalitas larva (Tabel 3).

Nilai GSI ditentukan berdasarkan persentase bo bot gonad dibagi dengan bobot badan induk. Data hasil pengamatan terhadap rataan nilai GSI pada ikan nila yang diberi vitamin E dengan dosis berbeda menunjukkan peningkatan seiring dengan meningkatnya dosis vitamin E yang diberikan. Namun pada penambahan dosis $300 \mathrm{mg} / \mathrm{kg}$ pakan, nilai GSI mengalami penurunan. Semua perlakuan yang diberi tambahan vitamin E memiliki nilai GSI yang lebih tinggi dibandingkan dengan kontrol. GSI tertinggi terdapat pada perlakuan penambahan vitamin E $225 \mathrm{mg} / \mathrm{kg}$ pakan dengan nilai GSI sebesar 1,87 $\pm 1,08 \%$ Meningkatnya nilai GSI pada perlakuan C (225 mg/kg pakan) diduga akibat peranan vitamin $\mathrm{E}$ dalam proses perkembangan gonad, yaitu vitamin $\mathrm{E}$ memengaruhi biosintesis vitelogonin atau proses vitelogenesis di hati. Oksidasi lemak yang terjadi pada saat vitelogonin dicegah dengan vitamin E sebagai antioksidan terhadap lemak. Hal ini menyebabkan pertambahan jumlah vitelogenin pada saat oosit dan meningkatkan bobot gonad sehingga persentase GSI menjadi lebih besar (Tang \& Affandi, 2004). Hasil serupa dilaporkan oleh Arfah et al. (2013) bahwa suplementasi vitamin E sebesar 375 $\mathrm{mg} / \mathrm{kg}$ pakan dapat meningkatkan nilai GSI pada ikan komet. Demikian juga penambahan vitamin E sebesar $800 \mathrm{mg} / \mathrm{kg}$ cacing tanah pada pakan ikan betutu merupakan dosis terbaik untuk meningkatkan kinerja reproduksi induk ikan betutu betina. Kemudian penambahan vitamin E sebanyak $375 \mathrm{mg} / \mathrm{kg}$ pakan merupakan dosis yang terbaik untuk mempercepat pematangan gonad ikan nilem selama enam minggu pemeliharaan (Tarigan et al., 2017). Adanya kandungan vitamin $E$ yang optimal dalam pakan akan mempercepat proses vitelogenesis sehingga akan semakin cepat pula proses pematangan gonad.

Hasil pengukuran terhadap rataan diameter telur pada penelitian ini disajikan pada Tabel 3. Ukuran diameter telur pada setiap perlakuan berkisar antara 2,04 $\pm 0,42$ sampai dengan $2,39 \pm 0,22 \mathrm{~mm}$; dan nilai ini relatif tidak berbeda antara perlakuan. Hasil penelitian ini serupa dengan yang dilaporkan oleh Nascimento et al. (2014) bahwa penambahan vitamin E dengan dosis 200, 300, 400, dan $500 \mathrm{mg} / \mathrm{kg}$ pakan pada ikan nila tidak memberikan perbedaan pada ukuran diameter telur. Namun, jika dibandingkan dengan hasil penelitian Darwisito et al. (2015) bahwa ukuran diameter telur pada penelitian ini relatif lebih besar. Ukuran diameter telur yang dilaporkan Darwisito et al. (2015) berkisar 1,71-2,00 mm dengan penambahan dosis vitamin $\mathrm{E} 150 \mathrm{mg} / \mathrm{kg}$ pakan dengan kandungan protein kasar 28\%30\% dan lemak kasar 6\%8\% Perbedaan respons ini diduga akibat dosis vitamin $\mathrm{E}$ dan kualitas pakan uji yang digunakan berbeda. Pada penelitian ini pakan uji yang digunakan mengandung protein dan

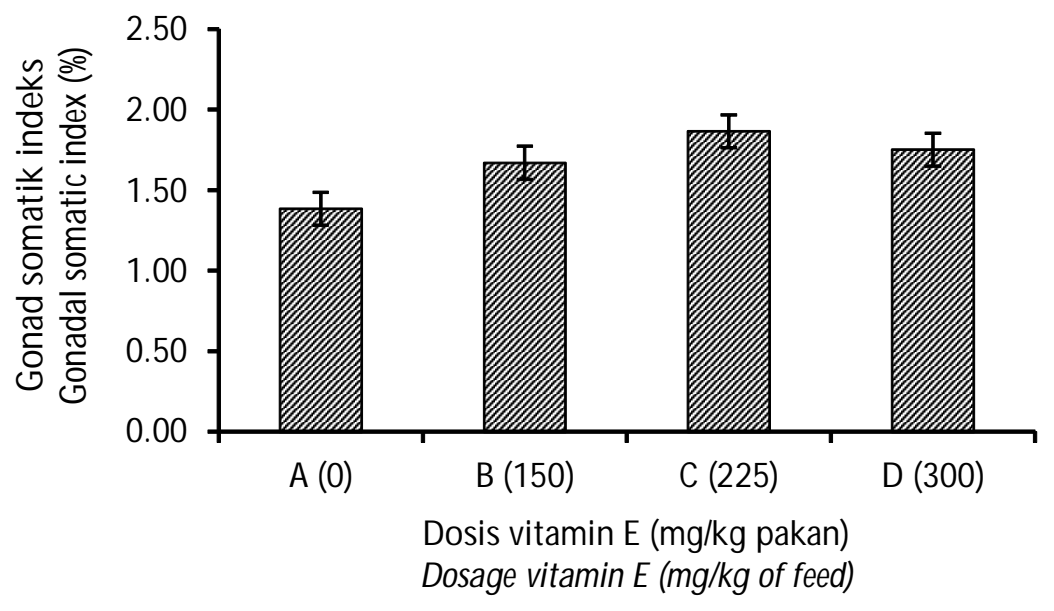

Gambar 1. Nilai gonad somatik indeks dengan penambahan vitamin E berbeda ( $n=$ lima ekor).

Figure 1. Gonadal somatic index values with the addition of different levels of vitamin $E$ ( $n=$ five fish). 
lemak kasar lebih tinggi yaitu 35,83\%36,13\%dan 8,17\% 9,79\% Kandungan vitamin E yang tinggi dalam pakan menyebabkan peningkatan vitelogonin di ovari semakin maksimal, yang memacu jumlah butiran telur yang terbentuk di dalam ovari semakin meningkat. Kondisi ini menyebabkan adanya penambahan ukuran sel telur yang diikuti dengan volume kuning telur semakin membesar yang berakibat ukuran diameter telur mengalami peningkatan (Napitu et al., 2013). Namun demikian penyerapan kuning telur (vitelogenesis) akan berhenti bila ukuran diameter telur telah mencapai maksimal (Arfah et al., 2013).

Penambahan vitamin E dengan dosis berbeda berpengaruh terhadap fekunditas individu ikan uji (Tabel 3). Hasil evaluasi menunjukkan bahwa penambahan vitamin E sebesar 225 dan $300 \mathrm{mg} / \mathrm{kg}$ pakan memberikan fekunditas individu tertinggi dibandingkan perlakuan lainnya. Hal ini menunjukkan bahwa performa reproduksi ikan nila dapat ditingkatkan secara maksimal dengan menambahkan vitamin E sintetis yang optimal ke dalam pakan. Menurut Hunt et al. (2004), bahwa vitamin E merupakan salah satu mikronutrien yang sangat diperlukan dan berperan penting dalam proses pertumbuhan, reproduksi, dan kesehatan ikan. Arfah et al. (2013) menyatakan bahwa penambahan vitamin E sebesar $375 \mathrm{mg} / \mathrm{kg}$ pakan ikan komet (Carassius auratus auratus) dapat meningkatkan kinerja reproduksi ikan tersebut seperti fekunditas dan germinal vesicle breakdown (GVBD). Mehrad et al. (2011) menyatakan bahwa penambahan vitamin E sebesar $1.000 \mathrm{mg} / \mathrm{kg}$ pakan dapat meningkatkan sintasan larva ikan zebra (Danio rerio). Kemudian Gammanpila et al. (2007) menyatakan bahwa vitamin E adalah salah satu mikronutiren penting yang berpengaruh terhadap performa reproduksi ikan. Vitamin E dalam pakan dapat meningkatkan keberhasilan pemijahan, fekunditas, serta vitelogenesis. Namun demikian, Tacon (1987) menyatakan bahwa kelebihan pemberian vitamin $\mathrm{E}$ dapat menyebabkan kematian pada ikan dan penurunan pertumbuhan, karena vitamin E bersifat toksik dalam hati. Hal ini juga diperkuat oleh pernyataan Halver (2002) bahwa vitamin E diketahui sebagai salah satu vitamin yang larut di dalam lemak, yang apabila diberikan dalam kadar yang tinggi dalam pakan akan mempunyai pengaruh negatif pada ikan. Demikian juga kekurangan vitamin E dalam pakan dapat menyebabkan terhambatnya pertumbuhan ovarium. Secara umum diketahui bahwa vitamin E berfungsi sebagai zat antioksidan, berperan dalam metabolisme asam nukleat dan juga berperan dalam meningkatkan sintesis hormon steroid yang berperan pada pematangan oosit. Namun demikian, pada penelitian ini nilai fekunditas tertinggi terdapat pada perlakuan $C$ dan $D$ yaitu penambahan dosis vitamin E 225 dan $300 \mathrm{mg} / \mathrm{kg}$ pakan. Hasil ini menunjukkan bahwa pada tingkat penambahan dosis tersebut diduga sudah mencapai batas optimum terhadap peningkatan fekunditas ikan nila. Menurut James et al. (2008), bahwa vitamin $\mathrm{E}$ berperan sebagai antioksidan yang dapat mencegah proses oksidasi lemak saat vitelogenesis sehingga menyebabkan vitelogenin yang masuk ke dalam oosit meningkat dan berakibat pada peningkatan bobot gonad.

Nilai derajat tetas telur (HR) pada penelitian ini berkisar antara 68,73 \pm 20,39\%sampai dengan 74,74 $\pm 19,75 \%$ Meningkatnya dosis vitamin E dalam pakan berakibat pada meningkatnya nilai HR (perlakuan B). Kemudian semakin bertambahnya dosis vitamin $\mathrm{E}$ dalam pakan sampai batas tertentu berakibat pada penurunan nilai HR (perlakuan C dan D). Namun demikian hasil ini menunjukkan bahwa nilai $\mathrm{HR}$ antar perlakuan relatif tidak berbeda. Kualitas telur yang baik direfleksikan dengan peningkatan derajat tetas telur dan total larva yang dihasilkan. Nilai HR perlakuan B (150 mg vitamin E/kg pakan) relatif lebih tinggi dibandingkan nilai HR pada perlakuan lainnya. Namun demikian jika dicermati pada parameter produksi larva (Gambar 2), perlakuan C (225 mg/kg) memiliki produksi larva tertinggi (37.927 ekor), sedangkan pada perlakuan B sebesar (21.637 ekor). Perbedaan ini karena nilai fekunditas pada perlakuan $\mathrm{C}$ jauh lebih

Tabel 3. Rataan diameter telur, fekunditas individu, derajat tetas telur, dan abnormalitas larva Table 3. Average of egg diameter, individual fecundity, hatching rate, and larvae abnormalities

\begin{tabular}{lcccc}
\hline $\begin{array}{c}\text { Perlakuan } \\
\text { Treatments }\end{array}$ & $\begin{array}{c}\text { Diamater telur } \\
\text { Egg diameter } \\
\text { (mm) }\end{array}$ & $\begin{array}{c}\text { Fekunditas individu } \\
\text { (larva/ekor) } \\
\text { Individual fecundity } \\
\text { (egg/fish) }\end{array}$ & $\begin{array}{c}\text { Derajat tetas telur } \\
\text { Hatching rate } \\
\text { (\%) }\end{array}$ & $\begin{array}{c}\text { Abnormalitas larva } \\
\text { Larval abnormalities } \\
\text { (\%) }\end{array}$ \\
\hline $\mathrm{A}(0)$ & $2.39 \pm 0.22$ & $1212 \pm 261$ & $68.73 \pm 20.39$ & $0.49 \pm 0.05$ \\
$\mathrm{~B}(150)$ & $2.32 \pm 0.32$ & $1158 \pm 129$ & $74.74 \pm 19.75$ & $1.99 \pm 0.55$ \\
C (225) & $2.25 \pm 0.54$ & $1886 \pm 513$ & $71.82 \pm 40.16$ & $1.25 \pm 0.76$ \\
D (300) & $2.31 \pm 0.26$ & $1929 \pm 271$ & $69.10 \pm 33.81$ & $1.28 \pm 0.82$ \\
\hline
\end{tabular}


tinggi dibandingkan dengan perlakuan B. Kebutuhan vitamin $\mathrm{E}$ untuk reproduksi berbeda untuk setiap spesies ikan. Kekurangan vitamin E pada pakan induk selain memengaruhi perkembangan gonad yang nantinya akan memengaruhi daya tetas telur, dapat pula menyebabkan beberapa penyakit ikan (Watanabe, 1988). Sesuai dengan peran vitamin E sebagai antioksidan makaasam lemak tidak jenuh pada fosfolipid dalam membran sel terlindungi (Hamre, 2011). Tingkat stres pada induk yang akan memijah akibat perubahan lingkungan dapat diturunkan dengan penambahan vitamin E dalam pakan (Jalali et al., 2008). Apabila oosit atau telur dalam perkembangannya tidak memperoleh vitamin E ini dalam jumlah yang cukup, maka telur akan menjadi busuk, diameter telur relatif kecil, dan derajat penetasan rendah, selanjutnya memungkinkan terjadinya derajat sintasan larva yang rendah. Jadi dengan adanya vitamin $\mathrm{E}$, maka asam lemak tidak jenuh terutama asam lemak esensial tidak teroksidasi, sehingga selanjutnya hasil reproduksi dapat ditingkatkan. Kebutuhan ikan terhadap vitamin E dalam ransum berbeda-beda bergantung kepada jenis dan umur ikan. Jenis ikan-ikan catfish kebutuhan vitamin E berkisar antara 60-240 mg/kg ransum ikan. Sedangkan untuk jenis salmonid membutuhkan vitamin E $35 \mathrm{mg} / \mathrm{kg}$ hingga $300 \mathrm{mg} / \mathrm{kg}$ pakan. Vitamin E dan asam lemak esensial dibutuhkan secara bersamaan untuk pematangan gonad ikan dan dosis vitamin $\mathrm{E}$ di dalam pakan akan bergantung kepada kandungan asam lemak esensial yang ada di dalam pakan tersebut. Semakin tinggi kandungan asam lemaknya, maka kebutuhan vitamin $\mathrm{E}$ juga semakin tinggi.

Abnormalitas larva ikan dapat diamati dari bentuk kepala, tubuh, dan atau ekor bengkok, tubuh menyusut atau lebih pendek dari ukuran normal maupun pembesaran kelopak mata. Nilai abnormalitas larva pada penelitian ini relatif kecil berkisar 0,49 $\pm 0,05 \%$ $1,99 \pm 0,55 \%$ diduga bahwa kadar vitamin E minimal dalam pakan uji tidak berakibat negatif terhadap abnormalitas larva. Demikian juga kandungan nutrien lain seperti protein, lemak, dan mineral dalam pakan uji masih sesuai untuk kebutuhan perkembangan larva normal, walaupun penambahan vitamin E di dalam pakan untuk masing-masing perlakuan berbeda.

Pengaruh penambahan vitamin $\mathrm{E}$ dengan dosis berbeda terhadap frekuensi pemijahan, jumlah induk memijah, total produksi larva, dan produktivitas induk selama penelitian ditunjukkan pada Gambar 2.

Hasil pengamatan kumulatif terhadap jumlah frekuensi pemijahan populasi terbanyak terjadi pada perlakuan pakan-C yaitu 28 kali, diikuti perlakuan-B 25 kali, perlakuan-D 22 kali, dan perlakuan-A 18 kali.
Demikian juga terdapatnya jumlah induk yang memijah, tertinggi diperoleh pada perlakuan-C sebanyak 17 ekor, diikuti perlakuan-D 15 ekor, perlakuan-B 14 ekor, dan perlakuan-A 12 ekor. Jika dicermati berdasarkan nomor tagging induk yang memijah menunjukkan bahwa terdapat induk nila yang memijah lebih satu kali selama penelitian, yaitu pada perlakuan-C terdapat 10 ekor, perlakuan-B delapan ekor, perlakuan-D empat ekor, dan perlakuan-A empat ekor. Total produksi larva tertinggi diperoleh pada perlakuan-C sebanyak 37.927 ekor kemudian diikuti perlakuan-D 29.325 ekor, perlakuanB 21.637 ekor, dan perlakuan-A terendah sebanyak 14.994 ekor. Penambahan vitamin E dalam pakan terbukti sangat efektif dapat meningkatkan produktivitas larva sebesar 78,55\%pada perlakuan-C; 56,46\%pada perlakuan-D; dan 23,69\%pada perlakuanB jika dibandingkan terhadap perlakuan-A (kontrol).

Jumlah induk memijah lebih tinggi pada induk yang diberi pakan dengan penambahan dosis vitamin E 225 mg/kg pakan yaitu 17 ekor, dengan frekuensi pemijahan 28 kali dengan total produksi larva 37.927 ekor, dan hasil terendah pada perlakuan kontrol (tanpa penambahan vitamin E) dengan jumlah induk memijah 12 ekor, frekuensi pemijahan 18 kali dan produksi larva 14.994 ekor. Hasil penelitian ini menunjukkan bahwa semakin tinggi penambahan vitamin $\mathrm{E}$ sampai dengan dosis penambahan $225 \mathrm{mg} / \mathrm{kg}$ pakan semakin tinggi jumlah frekuensi pemijahan, jumlah induk memijah, dan total produksi larva yang dihasilkan. Namun demikian, meningkatnya penambahan dosis vitamin E pada pakan (300 mg/kg pakan) justru menurunkan jumlah induk memijah dan produksi larva total. Kelebihan dosis vitamin E dapat bersifat toksik pada hati. Untuk mencegah sifat toksik tersebut, vitamin E akan disekresikan dari tubuh melalui saluran empedu dan urine (Pour et al., 2011). Oleh karena itu, dapat diduga bahwa untuk mengurangi sifat toksik vitamin E pada hati, maka kelebihan vitamin E tersebut disekresikan, sehingga vitamin E yang terakumulasi pada gonad menjadi lebih sedikit. Penambahan vitamin E dalam pakan dengan jumlah yang sesuai kebutuhan pada setiap jenis ikan dapat meningkatkan performa reproduksi, sistem imun, dan kualitas daging pada ikan yang dibudidayakan. Beberapa faktor yang memengaruhi keberhasilan pemijahan adalah lingkungan pemeliharan, kualitas pakan, umur ikan, dan kondisi kesehatan ikan. Halver (2002) melaporkan bahwa komposisi pakan yang lebih baik dapat mempercepat perkembangan gonad dan meningkatkan fekunditas ikan. Vitamin E yang telah diserap oleh oosit saat vitelogenesis akan terakumulasi dan terus bertambah hingga akhir vitelogenesis. Berdasarkan hasil analisis kadar vitamin E gonad pada akhir 

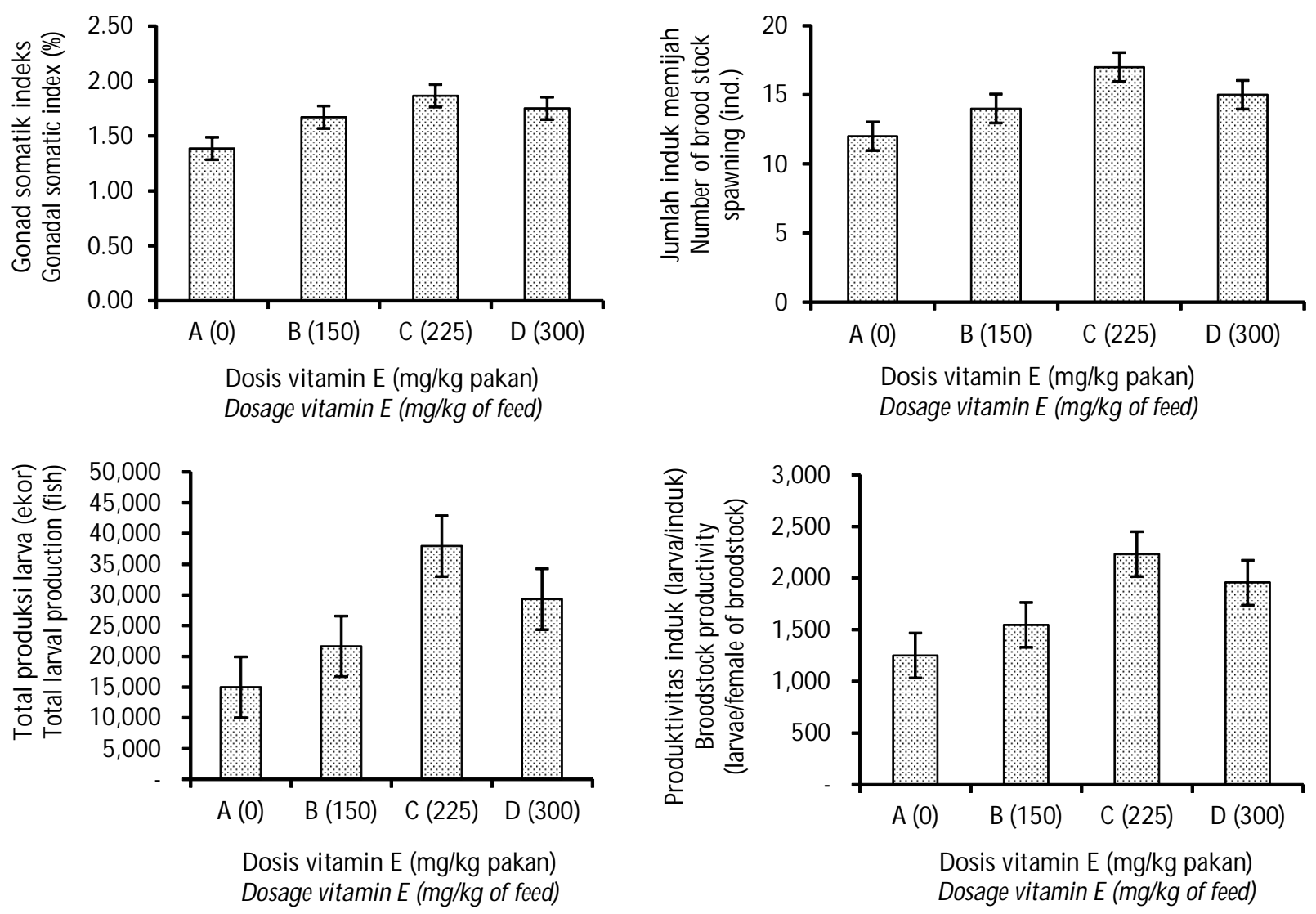

Gambar 2. Frekuensi pemijahan (a), jumlah induk memijah (b), total produksi larva (c), dan produktivitas induk selama penelitian (d).

Figure 2. Frequency of spawning (a), number of brood stock spawning (b), total larval production (c), and broodstock productivity during the study (d).

percobaan diketahui bahwa konsentrasi vitamin $\mathrm{E}$ tertinggi yang terakumulasi dalam gonad adalah pada perlakuan-D yaitu sebesar $286,5 \mu \mathrm{g} / \mathrm{g}$ gonad; kemudian pada perlakuan-C 243,8 $\mu \mathrm{g} / \mathrm{g}$ gonad; perlakuan-B 219,9 $\mu \mathrm{g} / \mathrm{g}$ gonad; dan terendah pada perlakuan yang tanpa penambahan vitamin $\mathrm{E}$ (kontrol) sebesar $51,8 \mu \mathrm{g} / \mathrm{g}$ gonad. Pada penelitian ini terdapat kenaikan kadar vitamin $E$ dalam telur seiring meningkatnya penambahan kadar vitamin $\mathrm{E}$ dalam pakan. Hasil penelitian sebelumnya dilaporkan oleh Yulfiperius et al. (2003) bahwa perbedaan konsentrasi vitamin E pada pakan akan memengaruhi kandungan vitamin E yang disimpan pada telur ikan patin (Pangasius hypophthalmus), dan semakin tinggi konsentrasi vitamin $\mathrm{E}$ dalam pakan, akan meningkatkan kandungan vitamin E dalam telur.

Hasil analisis kualitas air selama pemeliharaan menunjukkan bahwa nilai-nilai parameter kualitas air masih dalam kisaran layak untuk digunakan sebagai media pemeliharaan ikan. Suhu air $29,80^{\circ} \mathrm{C}-32,90^{\circ} \mathrm{C}$; pH 6,47-6,83; oksigen terlarut 1,10-7,56 mg/L; amonia
$\left(\mathrm{NH}_{3}\right)$ 0,08-1,19 mg/L; dan nitrit $\left(\mathrm{NO}_{2}\right)$ 0,05-0,08 $\mathrm{mg} / \mathrm{L}$.

\section{KESIMPULAN}

Penambahan vitamin E dalam pakan dapat meningkatkan performa reproduksi ikan nila. Penambahan vitamin E 225 mg/kg pakan meningkatkan produksi larva 78,55\%lebih tinggi dibanding dengan kontrol (tanpa penambahan vitamin E). Vitami E pada dosis tersebut juga menghasilkan jumlah induk memijah terbanyak (85\%) dengan total pemijahan sebanyak 28 kali, dan fekunditas individu sebesar $1.886 \pm 513$ butir per ekor induk.

\section{UCAPAN TERIMA KASIH}

Penelitian ini dilaksanakan dengan pendanaan APBN Balai Riset Pemuliaan Ikan Sukamandi, Kementerian Kelautan dan Perikanan. Penulis juga mengucapkan terima kasih kepada Sdr. Tatang Rustandi dan Puji Suwargono atas bantuannya sebagai teknisi yang terlibat dalam pelaksanaan penelitian ini. 


\section{DAFTAR ACUAN}

Arfah, H., Melati, \& Setiawati, M. (2013). Suplementasi vitamin $\mathrm{E}$ dengan dosis berbeda pada pakan terhadap kinerja reproduksi induk betina ikan komet (Carassius auratus auratus). Jurnal Akuakultur Indonesia, 12, 14-18.

Celik, F. \& Altun, T. (2009). Effects fo different levels of vitamin $\mathrm{E}$ on some growth parameters and gonadal histology of tilapia Oerochromis niloticus L., 1758 fingerlings. Journal of Animal and Veteriny Advances, 8(4), 643-649.

Coldebella, I.J., Neto, J., Mallmann, R., \& Veiverberg, C.A. (2011). The effects of different protein levels in the diet on reproductive of Rhamdia quelen females. Amsterdam. Aquaculture, 312(1), 137-144.

Darwisito, S., Sinjal, H.J., \& Wahyuni, I. (2015). Tingkat perkembangan gonad, kualitas telur dan ketahanan hidup larva ikan nila (Oreochromis niloticus) berdasarkan perbedaan salinitas. Jurnal LPPM Bidang Sains dan Teknologi, 2(2), 86-94.

Gammanpila, M., Yakupitiyage, A., \& Bart, A.N. (2007). Evaluation of the effects of dietary vitamin $C, E$, and zinc supplementation on reproductive performance of nile tilapia (Oreochromis niloticus). Aquaculture Science, 12, 39-60.

Halver, J.E. (2002). The vitamins. In Halver, J.E. \& Hardy, R.W. (Eds.). Fish Nutrition. 3rd Edition. San Diego CA, USA: Academic Press, p. 61-141.

Hamre, K. (2011). Metabolism, interactions, requirements and functions of vitamin $E$ in fish. Aquaculture Nutrition, 17, 98-115.

Hunt, A.O., Ozkan, F.,\& Altun, T. (2004). Effect of broodstock nutrition on reproductive performance of fish. Turkish Journal of Aquatic Life, 2(3), 487-493.

Ispir, U., Yonar, M.E., \& Oz, O.B. (2011). Effect of dietary vitamin E supplementation on the blood parameters of nile tilapia (Oreochromis niloticus). The Journal of Animal \& Plant Sciences, 21(3), 566569.

Izquierdo, M.S., Fernandez, P.H., \& Tacon, A.G.J. (2001). Effect of broodstock nutrition on reproductive performance of fish. Aquaculture, 197, 25-42.

Jalali, M.A., Hosseini, S.A., \& Imanpour, M.R. (2008). Effect of vitamin $E$ and highly unsaturated fatty acid enriched Artemia urmiana on growth performance, survival and stress resistance of Beluga (Huso huso) larvae. Aquaculture Research, 39, 1286-1291.
James, R., Vasudhevan, I., \& Sampath, K. (2008). Effect of dietary vitamin $E$ on growth, fecundity, and leukocyte count in goldfish (Carassius auratus). The Israeli Journal of Aquaculture, 19, 121-127.

Mehrad, B., Japaryan, H., \& Taati, M.M. (2011). Assessment of the effect of dietary vitamin $E$ on growth performance and reproduction of zebra fish, Danio reiro (Pisces, cyprinidae). Journal of Oceanography and Marine Science, E(1), 1-7.

Miao, W. (2018). Aquaculture production and trade trends: carp, tilapia and shrimp. Final Workshop Strengthening Capacities, Policies and National Action Plans on Prudent and Responsible Use of Antimicrobials in Fisheries. http://www.fao.org/fi/staticmedia/ MeetingDocuments/Work-shopAM R17/presentations/ 28.pdf.

Mokoginta, I., Jusadi, D., Setiawati, M., \& Suprayudi, A. (2000). Kebutuhan asam lemak esensial, vitamin dan mineral dalam pakan induk Pangasius suchi untuk reproduksi. Hibah bersaing VII/1-2 Perguruan Tinggi/Tahun Anggaran 1998/2000. Institut Pertanian Bogor. Laporan Akhir, $54 \mathrm{hlm}$.

Napitu, R., Limin, S., \& Suparmono. (2013). Pengaruh penambahan vitamin E pada pakan berbasis tepung ikan rucah terhadap kematangan gonad ikan nila merah (Oreocromis niloticus). J. Rekayasa dan Teknologi Budidaya Perairan, 1, 110-116.

Nascimento, T.S.R., Stéfani, M.V.D., Malheiros, E.B., $\&$ Koberstein, T.C.D. (2014). High levels of dietary vitamin $\mathrm{E}$ improve the reproductive performance of female Oreochromis niloticus. Acta Scientiarum, Biological Sciences M aringá, 36, 19-26.

National Research Council [NRC]). (1983). Nutrient requirement of warm water fishes and shellfishes. Washington D.C.: National Academy of Sciences Press, 102 pp.

Pamungkas, W., Tahapari, E., \& Darmawan, J. (2014). Gonadal development and spawning frequency of tilapia (Oreocromis niloticus) that feeded by vitamin E suplementation. Berita Biologi, 13, 239-244.

Pour, H.A., Sis, N.M., Razlighi, S.N., Azar, M.S., Babazadeh, M.H., Maddah, M.T., Reazei, N., \& Namvari, M. (2011). Effect of vitamin E on ruminant animal. Annals of Biological Research, 2, 244-251.

Pusat Data Statistik dan Informasi. (2018). Satu data produksi kelautan dan perikanan Tahun 2017. Jakarta: Kementerian Kelautan dan Perikanan, $590 \mathrm{hlm}$.

Roy, A. \& Mollah, M.F.A. (2009). Effects of different dietary levels of vitamin $E$ on the ovarian deve- 
lopment and breeding performances of Clarias batrachus (Linnaeus). Journal of Bangladesh Agricultural University, 7(1), 183-191.

Serezli, R., Akhan, S., \& Sonay, F.D. (2010). The effect of vitamin E on black sea trout (Salmo labrax) broodstock performance. Kafkas Univ. Vet. Fak Derg 16, (Suppl-B): p. 219-222.

Sukendi. (2005). Pengaruh kombinasi penyuntikan hCG dan ekstrak kelenjar hipofisa ikan mas (Cyprinus carpio L.) terhadap daya rangsang ovulasi dan kualitas telur ikan baung (Mystus nemurus CV). Jurnal Perikanan dan Kelautan, 102, 75-81.

Tacon, A.G.J. (1987). Nutrition and feeding of farmed fish and shirmp. A Training Manual 1. The Essential Nutrients. Food and Agriculture Organization of The United Nations Brasilla. Brazil, 117 pp.

Takeuchi, T. (1988). Laboratory work. Chemical evaluation of dietary nutrients. In Fish nutrition and mariculture. JICA textbook, the general aquaculture course. Watanabe, T. (Ed.). Japan International Cooperation Agency, p. 179-233.

Tang, M.U. \& Affandi, R. (2004). Biologi reproduksi ikan. Pusat Penelitian Kawasan Pantai dan Perairan. Pekanbaru: Universitas Riau, $110 \mathrm{hlm}$.

Tarigan, N., Supriatna, I., Setiadi, M.A., \& Affandi, R. (2017). Pengaruh vitamin E dalam pakan terhadap pematangan gonad ikan nilem (Ostheochilus hasselti,
CV). Jurnal Perikanan Universitas Gadjah Mada, 19(1), 1-9.

Utomo, N.B.P. (2009). Peningkatan mutu reproduksi ikan hias melalui pemberian kombinasi asam lemak esensial dan vitamin E dalam pakan ikan zebra (Danio rerio). Disertasi. Sekolah Pasca Sarjana. Institut Pertanian Bogor.

Utomo, N.B.P., Zairin, M., Yusuf, T.L., Mokoginta, I., \& Bintang, M. (2005). Pengaruh pemberian vitamin $E$ dengan level berbeda terhadap kinerja reproduksi ikan zebra (Danio rerio). Jurnal Akuakultur Indonesia, 4(2), 125-129.

Wahyudi, D., Zairin, M.Jr., \& Suprayudi, M.A. (2016). Pengaruh pemberian vitamin $\mathrm{E}$ (a-tokoferol) terhadap kinerja reproduksi ikan betutu Oxyeleotris marmorata Bleeker 1852. Jurnal Iktiologi Indonesia, 16(1),103-113.

Waagbø, R. (2010). Water-soluble vitamins in fish ontogeny. Aquaculture Research, 41, 733-744.

Watanabe, T. (1988). Importance of the study of broodstock nutrition for futher development of aquaculture. In Nutrition and feeding in fish. London: Academic Press, p. 395-414.

Yulfiperius, Mokoginta, I., \& Jusadi, D. (2003). Pengaruh kadar vitamin E dalam pakan terhadap kualitas telur ikan patin (Pangasius hypophthalmus). Jurnal Ikhtiologi Indonesia, 3(1), 11-18. 